\title{
VERGILIAN COMMENTATORS ON HOMERIC ELEMENTS IN AEN. 1, 81FF. ${ }^{1}$
}

The scene in Aeneid 1 in which Aeneas first appears is one of the most interesting passages of the poem from the point of view of Vergil's use of references to Homer. Not only does he model the scene of the storm sent by Iuno in which Aeneas and his companions almost perish on the Odyssey $(5,291 \mathrm{ff}$.), where Odysseus himself almost dies in a storm sent by Poseidon, making sure that his model is easy to recognize through a series of references that are close adaptations and even accurate translations from Homer, but he also combines them with references to other scenes from the Homeric epics and echoes of Hellenistic and Roman poets. The first part of this article analyzes Vergil's references to Homer in Aen. 1, 81-105, highlighting his approach to intertextuality, but also on the role these references play in his portrayal of Aeneas. The second part of the article focuses on the way these adaptations from Homer were viewed by Vergil's ancient readers. It is shown that three notes in the Servius Danielis (on Aen. 1, 85; Aen. 1, 92; and Aen. 1,94) reflect a tradition of comparative analysis of the two scenes (Aen. 1, 81ff. and Od. 5, 291ff.), in which ancient critics recognized, but did not always commend Vergil's use of Homer. The discussion of $S D$ ad Aen. 1, 92 involves an examination of the textual

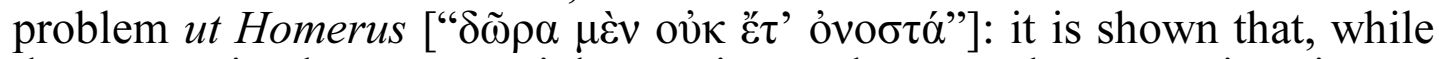
the transmitted text certainly carries a lacuna, the quotation is not interpolation (as has been previously supposed) but belongs in this note, and a reconstruction of the scholarly reasoning that led from ut Homerus to

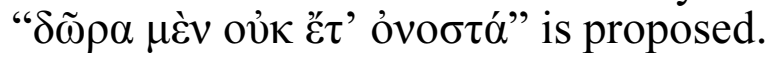

Key words: Vergil, Homer, intertexuality, Aeneid, Odyssey, Servius, Servius Danielis, Tiberius Claudius Donatus, Aelius Donatus, Macrobius.

М. Н. Казанская

(Институт лингвистических исследований РАН)

\section{Античные комментаторы о гомеровских аллюзиях в Aen. 1, 81ff.}

Сцена из первой песни Энеиды, в которой впервые появляется Эней, представляет собой один из наиболее интересных пассажей у Вергилия с точки зрения использования аллюзий и отсылок к Гомеру. Вергилий опирается на описание морской бури, посланной Посей-

\footnotetext{
${ }^{1}$ This article was written as part of the collective project on translation and literary adaptation in Late Antiquity and in the Middle Ages, hosted by the Institute for Linguistic Studies and funded by the Russian Science Foundation (project № 17-18-01624 «Перевод и языковая адаптация в литературных текстах средневековой Европы»).
} 
доном, в пятой песни Oдиссеи как модель для сцены бури, посланной Юноной, от которой еле спаслись Эней и его спутники. При этом Вергилий обеспечивает узнаваемость интертекста за счет целой череды стихов, передающих, иногда почти дословно, выражения из Od. 5, 291 и след., но одновременно сочетая их с аллюзиями на другие пассажи из гомеровских поэма также на тексты эллинистических поэтов и своих римских предшественников. В первой части статьи предлагается подробный разбор гомеровских аллюзий в Aen. 1, 81105, причем особое внимание уделяется подходу Вергилия к интертекстуальности и той роли, которую играют эти аллюзии в общем изображении характера Энея. Вторая часть статьи посвящена тому, как античные читатели воспринимали использование Гомера в данном эпизоде: три заметки (к стихам Aen. 1, 85, 92 и 94) в расширенной версии комментарии Сервия к Энеиде (так называемая версия Сервия Даниеля) отражают традицию сопоставительного анализа сцен бури из Aen. 1 и $O d .5$, причем античные критики далеко не всегда хвалили то, как Вергилий адаптировал гомеровский материал. Обсуждение комментария SD ad Aen. 1, 92 включает разбор текстологически

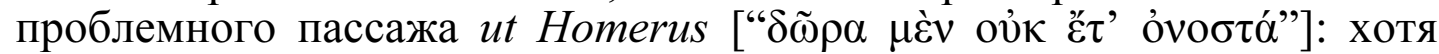
текст несомненно испорчен, греческая цитата не является случайной интерполяцией, как предполагалось ранее, но была привлечена как параллель в исходном тексте; также предлагается реконструкция аргументации источника Сервия Даниеля, дающая представление, о чем могла идти речь в лакуне между словами ut Homerus и $\delta \tilde{\omega} \rho \alpha \mu \varepsilon \grave{v}$

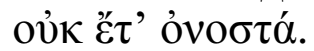

Ключевые слова: Вергилий, Гомер, интертекстуальность, Энеида, Oдиссея, Сервий, Сервий Даниеля (Servius Danielis), Тиберий Клавдий Донат, Элий Донат, Макробий.

Aeneas makes his first appearance in the Aeneid as Iuno sends a storm to destroy the Trojan fleet: she engages Aeolus to let the four cardinal winds out to blow at once (Aen. 1, 65-87), creating the storm that will only be stopped by Poseidon (Aen. 1, 126-156). Ancient readers of the Aeneid already recognized that this scene was closely modelled on the Homeric description of the storm sent by Poseidon to kill Odysseus ( Od. 5, 292ff.). The Homeric intertext transpires as the model for the storm in the Aeneid on several levels of the text. Not only does Virgil reproduce the overall structure of the scene: a vengeful deity states the reasons for wishing to harm the hero in a soliloquy (Aen. 1, 37-49; cf. Od. 5, 286-290); the winds are let out on the hero at sea (Aen. 1, 81-87; Od. 5, 292-296); the hero fears for his life (Aen. 1, 92-93, cf. Od. 5, 297-298), and exclaims to the heavens wishing he had died at Troy (Aen. 1, 94101, cf. Od. 5, 299-312); the rising wave is about to kill the hero, when a god intervenes and calms the sea (Neptune at Aen. 1, 124ff.; Athena at $\mathrm{Od} .5,382 \mathrm{ff}$.); the hero reaches land, and it will prove an important point on his way to his final destination, providing space 
for repose and recollection (Aeneas and his companions manage to reach the shore by Carthage; Odysseus is washed ashore in the land of Phaeacians). Vergil also models a number of his verses on Homer, at times, by closely imitating or even translating expressions from the Odyssey, sometimes by deliberately reproducing distinctive features of Homeric style.

This article aims at reconstructing the ancient scholarly tradition on the episode of the storm in Aen. 1, 81ff. and, in particular, at how the critics perceived Vergil's reception of Homer. Limiting the material presented a particular problem: we chose to focus on the passage where Servius and Servius Danielis systematically show awareness of Homer's influence, i. e. verses 81-105. While the choice of this passage was primarily guided by the comments of ancient scholars, it is not totally arbitrary, even from the point of view of Vergil's narrative and techniques of intertextuality. Indeed, the preceding narrative, Iuno's soliloquy and her conversation with Aeolus, are not devoid of Homeric allusions, but these are sporadic and for the most part belong to the type of reference that R. F. Thomas has called the "casual reference", i. e. expression that is meant to recall in the reader's memory a certain poetic precedent without alluding to a precise passage ${ }^{2}$. Thus, the expression et soror, et coniunx (Aen. 1, 47) is a translation of Homer's double

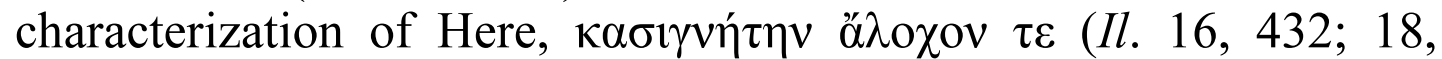
356). Similarly, divum pater atque hominum rex (Aen. 1, 65) is a

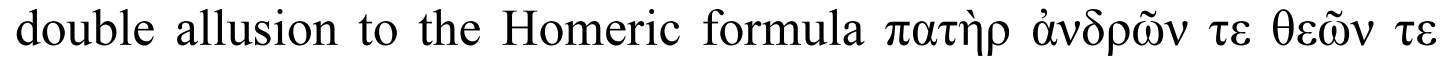
(Il. $-12 \mathrm{x}, \mathrm{Od} .-3 \mathrm{x})$ and to Ennius' adaptation of it (divom pater atque hominum rex, Ann. 175; for other rendering of this formula, cf. Ann. 580 and 581) ${ }^{3}$. The expression formā pulcherrima (Aen. 1, 72 ), used by Iuno to describe Deiopea whose hand in marriage she promises to Aeolus in exchange for his help, seems to be an accurate

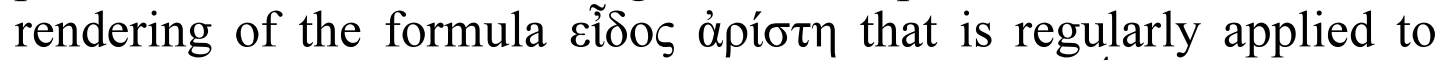
women of outstanding beauty in the Homeric epics ${ }^{4}$. None of these

2 "[Casual reference] is quite simply the use of language which recalls a specific antecedent, but only in a general sense, where the existence of that antecedent is only minimally important to the new context, where, one could say, an atmosphere, but little more is invoked" (Thomas 1986: 175).

${ }^{3}$ The fact that Vergil fully felt its formulaic nature is evident from the fact that he will reuse it in several other contexts: cf. Aen. 2, 648; 10, 2; 10, 743. ${ }^{4}$ Cf. Il. 2, 715; 3, 124; 6, 252; 13, 356; 13, 378; Od. 7, 57. The expression also appears in the Homeric hymns (Hymn. Dem. 146; Hymn. Aphr. $41-$ the latter is the sole example of the formula applied to a goddess, cf. Faulkner 2008, 127 ad loc.). Vergil's rendering of the expression into Latin, forma a pulcherrima, will once more be used of Dido (Aen. 1, 496). 
expressions are meant to evoke a specific passage from the Homeric epics: their presence and recognizable form highlight the fact that the scene where Iuno solicits Aeolus is modelled on the scene from the Iliad where Here turned to Hypnos for help in seducing Zeus (Il. 14, 231ff.).

The case with elements of Homeric diction in the episode of the storm is more complex. Vergil not only models this part of his narrative - in the general outlines, but also in specific details after the storm sent by Poseidon in Odyssey 5, but makes sure that his readers recognize Odyssey 5 as his model by reproducing, sometimes word for word, specific elements of Homer's narrative. Besides these, we also discover a number of expressions that evoke Homer's style in general or even Alexandrian discussions of specific elements of Homer's diction, or to use, once again, Thomas' terminology, we are dealing with multiple single references to the scene that Vergil chose as his model, enriched by a number of corrections and conflations ${ }^{5}$. Ancient readers already recognized that Vergil's use of Homeric material in the episode of the sea-storm was much profounder than usual, so that Macrobius even renounces giving a full list of parallels between Vergil's and Homer's seastorms (from Aen. 1, 81ff. and from Od. 5, 291ff., accordingly) as being too numerous ${ }^{6}$. We will start by giving a linear commentary on Vergil's reworking of Homer (v. 81-105), and then proceed to outline the ancient critics' views on the issue.

ac venti velut agmine facto... ( $v$. 82). The conjunction velut indicates that a simile of the epic type is being introduced (even though in this case it will not be extensive). However, Vergil inverses the structure typical for Homeric comparisons, where

\footnotetext{
${ }^{5}$ In Thomas' terminology single references are ones that are introduced so that "the reader recall the context of the model and apply that context to the new situation; such reference thereby becomes a means of imparting great significance, of making connections or conveying ideas on a level of intense subtlety" (Thomas 1986, 177). Corrections occur when "the poet provides unmistakable indications of his source, then proceeds to offer detail which contradicts or alters that source" (Thomas 1986, 185), and conflations involve referring simultaneously to multiple sources (Thomas 1986, 193).

${ }^{6}$ Cf. tempestas Aeneae Aeolo concitante cum allocutione ducis res suas conclamantis de Ulixis tempestate et allocutione descripta est, in qua Aeoli locum Neptunus obtinuit. versus, quoniam utrobique multi sunt, non inserui: qui volet legere ex hoc versu habebit exordium: "haec ubi dicta, cavum conversa cuspide montem", et apud Homerum de quinto Odysseae:

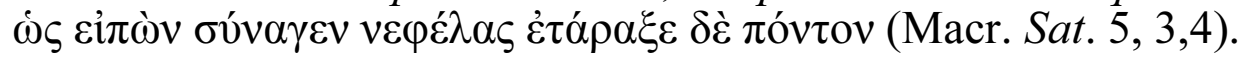


human actions are likened to the impetus and the force of stormy winds ${ }^{7}$ : here the winds, rushing forth from the cave, are likened to an attacking army. The full extent of Vergil's transformation of the traditional comparison will become evident at Aen. 1, 148-156 where Poseidon, as he is placating the winds, is compared to a skillful and respected statesman capable of pacifying a rebellious crowd $^{8}$.

una Eurusque Notusque ruunt creberque procellis / Africus... (v. 85-86). This line reproduces closely the list of winds in the

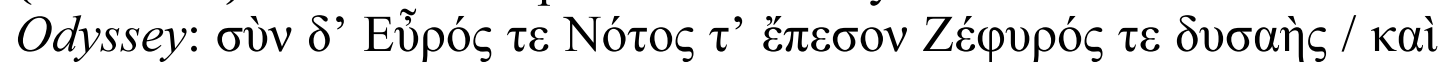

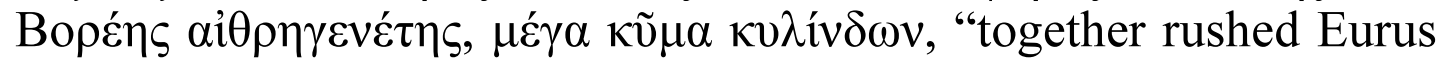
and Notus, and the stormy Zephyrus, and Boreas, born of clear skies, rolling the great a great wave" (Od. 5, 295-296). This, incidentally, is the only passage in which Homer lists all the cardinal winds at once, emphasizing the absolute havoc of the storm that they will create ${ }^{9}$. The beginning reproduces with remarkable accuracy

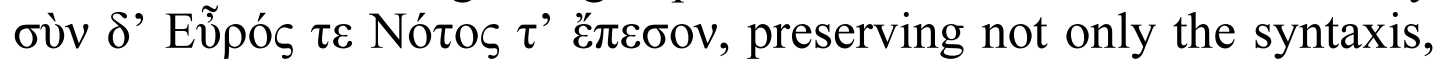
but also the metrical structure of the original, the sole difference

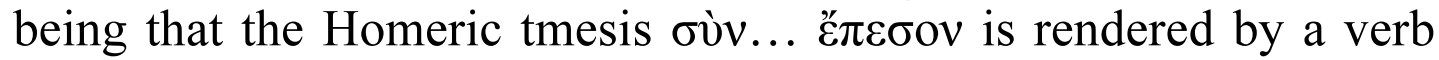
with an adverb (una... ruunt). Homer's Zźpvoos is replaced by Africus (a south-wester associated with storms) ${ }^{10}$, which is well

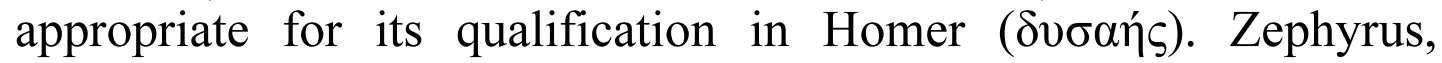
however, will be mentioned by Vergil later on, as Neptune intervenes and restores the calm at sea (v. 131). The general meaning of $\delta v \sigma \alpha \eta$ 's is rendered by creber procellis, adjective with depending ablative. The fourth of the cardinal winds, Boreas, is missing from Vergil's list at this point, but will be mentioned after Aeneas' speech

\footnotetext{
${ }^{7}$ For multiple passages in Homeric epics where this traditional comparison appears, see Scott (1974: 62-66).

${ }^{8}$ Once again, traditionally, it is the human unrest that would be compared to winds coming head-to-head in a storm, not the other way around (cf. especially Il. 2, 144-149). This comparison of Neptune with statesman before a rebellious crowd is one of the famous comparisons in the Aeneid (see the detailed analysis in Galinsky 1996: 20-24).

${ }^{9}$ Usually a storm in Homer is raised by a conflict of two winds (cf. Hainsworth on Od. 5, 280 in Heubeck, West, Hainsworth 1988: 280); on the effect of the mention of all four cardinal winds, cf. I. J. F. de Jong (2001: 140).

${ }^{10}$ See Austin (1971: 53, ad Aen. 1, 86). It is worth noting that Vergil chose a wind that resembles Ź́์ Zephyrus' overall pleasant associations (cf. the Homeric scholia that point

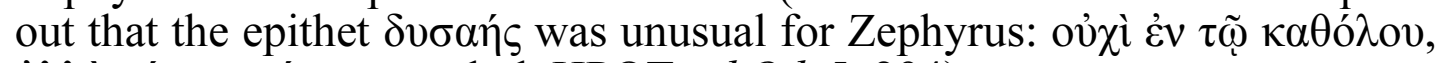

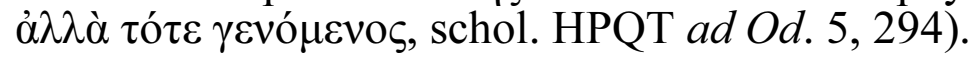


at Aen. 1, 102, as the narrative returns to the description of the storm. We know that this line drew attention of ancient scholars Seneca criticized Vergil's depiction of three winds blowing at once as impossible (Sen. Quest. Nat. 16).

eripiunt subito nubes caelumque diemque / Teucrorum ex oculis; ponto nox incubat atra (v. 88-89). These lines reproduce

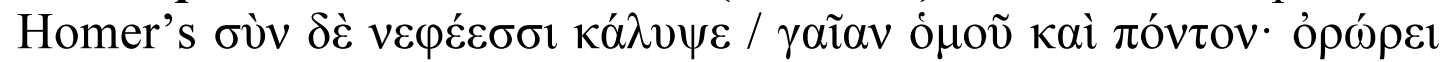
$\delta$ ' oúpavó $\theta \varepsilon v$ ví $\xi$, "and he shrouded with clouds the earth and sea: and night swept down from the sky" (Od. 5, 293-294), albeit with several modifications. Vergil has modified the syntactical construction (changing the subject from Poseidon to the clouds themselves), adding the focalization on the Trojans (Teucrorum ex oculis), but most importantly he has eliminated Homer's opposition


remains in ponto nox incubat atra) as it was no longer consistent with the focalization on the Trojans, who could not have known what was happening on land; however, an echo of the binary

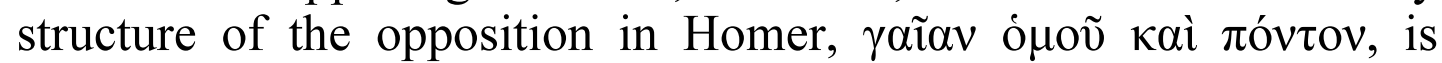
reflected in Vergil's hendiadys caelumque diemque.

extemplo Aeneae solvuntur frigore membra (v. 92). Given the number of allusions to the sea-storm in the Odyssey, Vergil's reader would be expecting that the description of Aeneas' fright would be

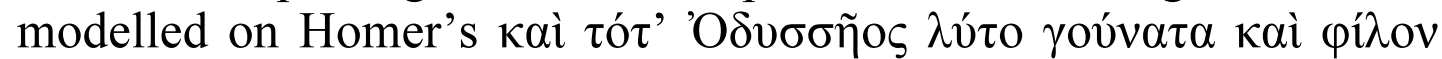
ทेंo $\rho$ "and then Odysseus' knees and his heart were loosened (i. e. lost strength)" (Od. 5, 297). However, already ancient readers recognized that the verse is a combination of two references, (a) to the formulaic expression regularly used by Homer to describe fright or despair, and (b) to Livius Andronicus' Ulixi cor frixit prae pavore "Ulysses' heart became numb with fear" (Od. fr. 18 Warmington). Vergil chose to replace the separate mention of the knees and of the heart by the broader term membra (this solution would have been suggested to him by the associated Homeric formula $\lambda \tilde{v} \sigma \varepsilon \delta \dot{\varepsilon}$

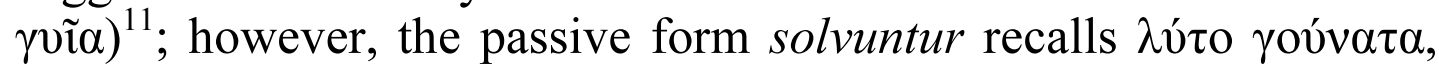
and the introduction of frigore implies the association with Livius Andronicus' cor frixit. As a result, Vergil's verse combines the two notions, the weakness and the numbness of Aeneas' limbs.

duplicis tendens ad sidera palmas (v. 93). At first glance, Vergil seems to be stepping away from his Homeric model in this line,

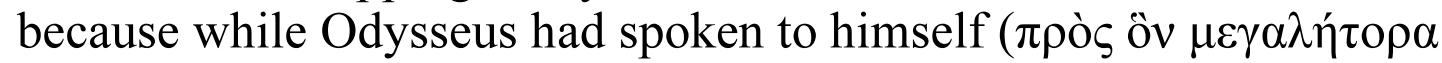

${ }^{11}$ On the use of $\gamma o u ́ v \alpha \tau^{\prime}$ '̌ $\lambda v \sigma \varepsilon$ and $\lambda \tilde{v} \sigma \varepsilon \delta \varepsilon \bar{\varepsilon} \gamma v \tilde{\imath} \alpha$ in Homer, see the recent article by Philpott (2016: especially 401-404). 


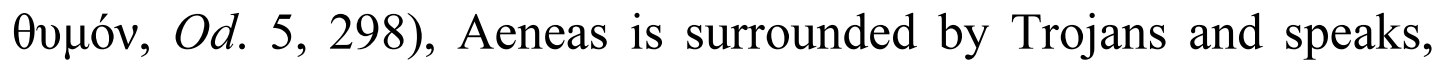
raising his hands to the skies. However, this line takes up a verse from the Iliad, where Nestor prays for the Achaeans, with the same

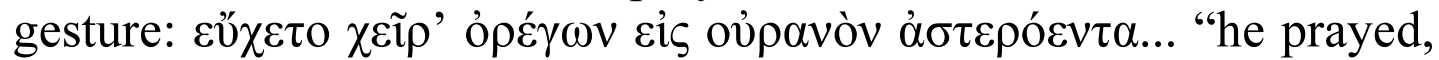
raising his hands to the starry sky" (Il. 15, 371; cf. Od. 9, 527 where the same verse introduces Polyphemus' plea for revenge) ${ }^{12}$. Vergil's rendering of this line is remarkable in that he seems to have taken into account ancient scholars' remarks on the verse, as preserved in the exegetical scholia:

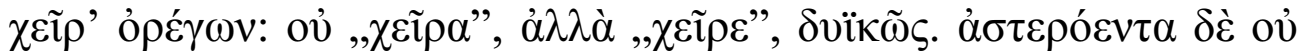

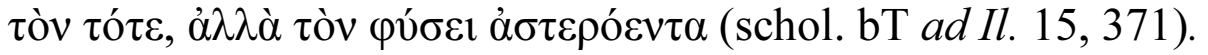

"stretching his hands: not 'hand' but 'two hands', dual. and 'starry' not as it was starry then, but starry by nature".

Indeed, Vergil's expression duplicis... palmas seems to emphasize that the original Homeric verse carried a dual form ${ }^{13}$. The words ad sidera renders the general sense of the expression cis oủpavòv $\dot{\alpha} \sigma \tau \varepsilon \rho \cos _{\varepsilon} \tau \alpha$, with Vergil carefully reproducing the discrepancy between the expression and the situation that is described: Nestor's prayer is pronounced in daytime, and the use of the epithetum ornans $\dot{\alpha} \sigma \tau \varepsilon \rho \operatorname{cov} \tau \alpha$ in this context seems to have presented a problem for ancient commentators, so much so that a part of them felt the need to defend the poet with the explanation ov $\tau$ òv $\tau$ ó $\tau \varepsilon$,

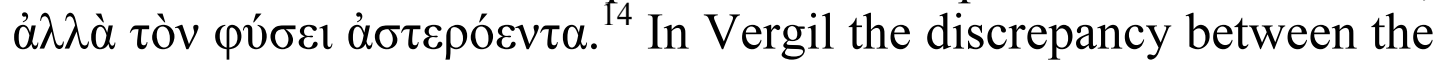

${ }^{12}$ This allusion is not recognized in the commentaries on the Aeneid (see, for example, Austin 1971: 55 ad Aen. 1, 93). Vergil chose to depart from his model by introducing a reference to a different passage in Homer, better suited for a speech pronounce before troops in distress; the choice of the verse introducing Nestor's speech in $I l .15,371$ might have been suggested to Vergil by the epic simile that follows immediately after Nestor' words (Il. 15, 379-385), where the attacking Trojans are likened to a great wave that sweeps down on a ship in storm.

${ }_{13}$ As the allusion to Il. 15, 371 is not noted by commentators on Aen. 1, 93, Vergil's use of duplicis is necessarily viewed as pleonastic (cf. Austin 1971: $55 \mathrm{ad} \mathrm{Aen.1,93)}$ or as referring to a gesture that required the use of both hands (Conington 1863: 42 ad Aen. 1, 93 cites the translation "clasped"; and Anderson 1993: 166-167 views the addition of duplicis as necessary indication for the suppliant's gesture). The expression duplicis... ad sidera palmas will be reused, with slight modifications, at Aen. 9, 16 and 10, 667 .

${ }^{14}$ The mention of the sky in combination with the gesture of raised hands and an address to Zeus, is formulaic in Homer, as demonstrated by Pucci (2012), who studied the shorter and more frequent version of the formula, Eis oúpavòv củpúv. For similar remarks on epitheta ornantia in the 
expression tendens ad sidera palmas and the described circumstances is even more manifest, as the poet has specifically emphasized that the storm had come in daylight, obscuring the sky (eripiunt subito nubes caelumque diemque, v. 88). Vergil's rendering of

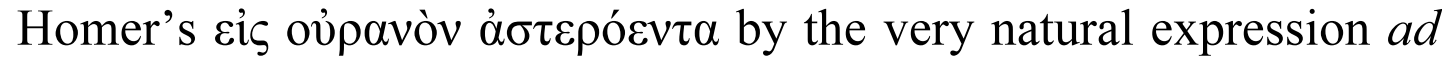
sidera, that is leaves the reader the possibility of interpreting it as a metonymy for the sky, shows that he agreed with those who defended Homer's use of the epithet, and he will make sure that the reader does not overlook ad sidera as a simple poetic gaffe by using the expression once more in v. 103 (fluctusque ad sidera tollit, "[the storm] raises the waves to the stars").

o terque quaterque beati... (v. 94). Aeneas' exclamation takes up the second part of Odysseus' soliloquy in Odyssey 5, as he cries out that he would have preferred to die by Troy:

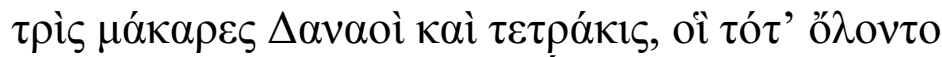

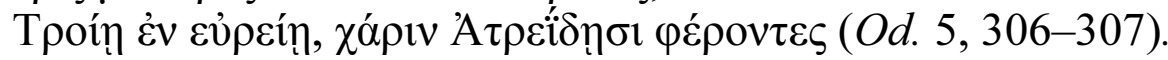

"O happy Danaans, three times over, four times over, those who perished in broad Troy, bringing service to the sons of Atreus".

However, a reader who remembers the Homeric episode, will be aware that Aeneas' train of thought is different from that of Odysseus': while Odysseus had wished he had died at Troy, as he was defending Achilles' corpse, because then he would at least have been buried in glory, instead of perishing at sea, Aeneas, confronted with mortal peril, exclaims that he would prefer to have died in his homeland ${ }^{15}$.

ubi tot Simois correpta sub undis / scuta virum galeasque et fortia corpora volvit! (v. 100-101). These two verses are a relatively free rendering of a different passage from the Iliad:

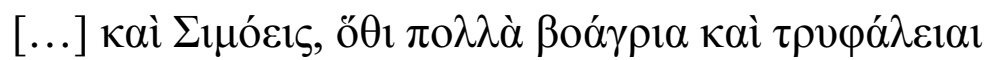

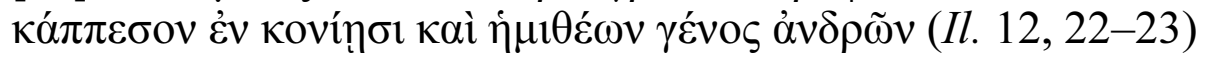

Homeric scholia, see schol. A ad Il. 8, 555a; schol. A ad Il. 21, 218a; schol. E ad Od. 6, 26; etc. The scholium bT ad Il. 15, 371 is cited by Nünlist (2009: 300) in his overview of the ancient critics' approach to Homeric epithets.

${ }^{15}$ See Gossage (1963: 134), Nehrkorn $(1971,569)$. On the other hand, Austin's summary of the difference in intent between the two speeches in his commentary (Austin 1971: 56 ad Aen. 1, 94ff.) does not appear accurate: "but then [Odysseus] laments the loss of glory from death in battle if he drowns, while Aeneas thinks of the brave men who are dead when he lives". 
"and Simois, where many ox-hide and helmets fell into dust, and the generation of half-divine men".

Naturally, as Aeneas had just mentioned the deaths of Hector and Sarpedon, and his own near escape of death at the hands of Diomedes $^{16}$, Vergil's reader would also be reminded by v. 100-101 of the episode of Scamandrus' wrath (Il. 21, 214ff.). The introduction of this second reference to the Iliad was suggested by Odysseus' mentioning of Achilles' death (Od. 5, 309-310), but it also allows Aeneas to round up his speech by suggesting that even a death without burial, but in the river that flows by Troy, would have been preferable to a death at sea. The ending of Aeneas' speech was significant for Vergil, who will repeat these verses with slight modifications in book 8, as Aeneas reflects on how many corpses will end up in the river Tiber, before the neighboring peoples in his new homeland, Italy, are subdued ${ }^{17}$ :

quas poenas mihi, Turne, dabis! quam multa sub undas scuta virum galeasque et fortia corpora volves,

Thybri pater! (Aen. 8, 538-540).

"What penalty will you pay me, Turnus! How many shields of men, and helmets, and strong bodies will you be rolling under you waves, o Father Tiber!"

insequitur cumulo praeruptus aquae mons (p. 105). The verse is part of an interesting conflation. In itself, it is a close translation of Apollonius Rhodius, as already Conington (1863: 43 ad Aen. 1, 105) recognized:



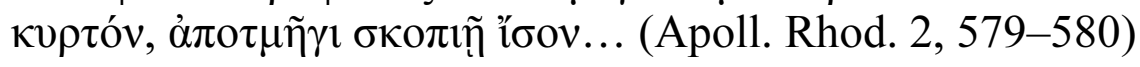

"and a great wave suddenly rose up from the depths before them, arched like a precipice."

But it was also inspired by the description of the great wave that descended upon Odysseus' raft as he was speaking:

\footnotetext{
${ }^{16}$ On the significance of the Iliadic episodes, evoked by Aeneas in his speech, see Pöschl (1962: 34-41), Nehrkorn (1971: 568-569).

${ }^{17}$ On how this intratextual allusion highlights the development of Aeneas' character, see Putnam (1995: 146-147), Barchiesi (2015: 79-80); cf. de Grummond (1977: 226ff.).
} 


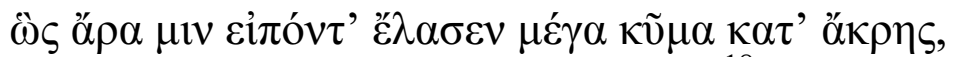

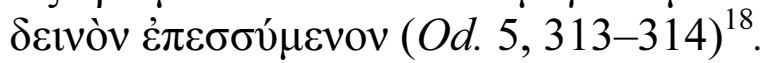

"as he said this, a great wave stroke him from on high, in a terrible rush."

These lines will be rendered quite accurately a little further, as Vergil shifts the description of the storm to Aeneas' perspective: ipsius ante oculos ingens a vertice pontus / in puppim ferit... "before his own eyes, an immense wave strikes the stern, from the very top" (Aen. 1, 114-115), where ingens... pontus corresponds to

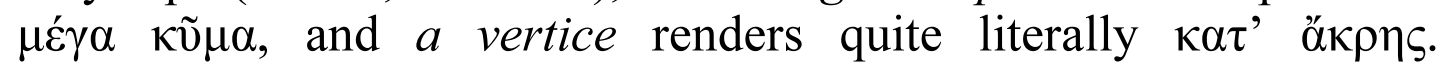
However, the verse 105 prepares the reader for translation in 114115 , in particular, with regard to the expression $\kappa \alpha \tau^{\prime}$ ö $\kappa \rho \eta \varsigma$ that had raised a discussion among ancient critics: the feminine form in particular seems to have presented a problem, and strands of the discussion are reflected in the scholia. Thus, according to one explanation, it was due to the ellipsis of $\kappa \varepsilon \varphi \alpha \lambda \tilde{\eta} \varsigma$ so that the meaning would be "from the top" (schol. ad Od. 5, $313 \mathrm{c1}$, c2, d2; cf. Eust. ad Il. 13, $772=3,552,17$ van der Valk), according to another, to the ellipsis of vๆós or $\sigma \chi \varepsilon \delta$ ín $\varsigma$, referring to Odysseus' raft (schol. ad Od. 5, $313 \mathrm{~d} 1$ and d2); some scholia glossed $\kappa \alpha \tau$ ' öк

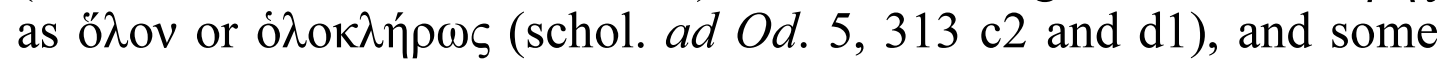
explained it as transferred from the destruction of a city ( $\kappa \alpha \tau^{\prime}$ 'o $\alpha \rho \alpha \varsigma$

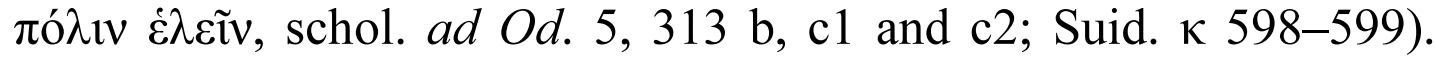
Vergil in his translation a vertice (v. 114) visibly agreed with the

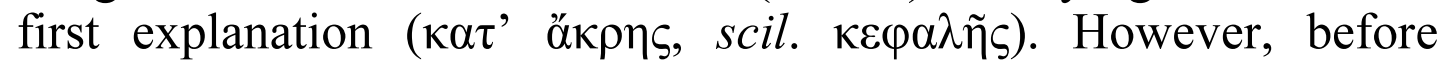
introducing this very apt adaptation of Homer's expression, he sought to prepare the reader for the associations of $\kappa \alpha \tau$ ' $\alpha \kappa \rho \eta \varsigma$, usually used by Homer in the context of the fall of a city (especially Troy) ${ }^{19}$, by introducing early on the metaphor of the wave as a great precipitous hill, and here the reference to Apollonius Rhodius served him well. Thus, the reader is not surprised by ingens a vertice pontus at v. 114-115 that accurately renders Homer's $\mu \varepsilon \gamma_{\alpha} \alpha \tilde{v} \mu \alpha$

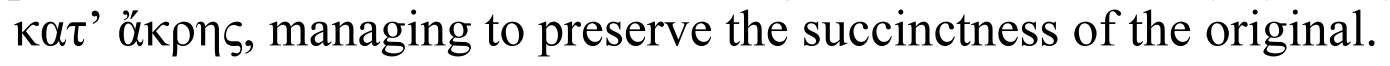

\footnotetext{
${ }^{18}$ The expression $\mu \varepsilon ́ \gamma \alpha \kappa \tilde{v} \mu \alpha$ also appeared as part of the characterization

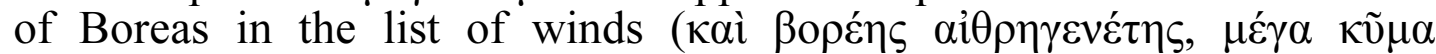
$\kappa v \lambda i v \delta \omega v, O d .5,297)$, and later in the description of Odysseus' battle with

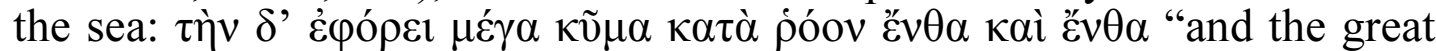
wave carried [his raft] to and fro, with its flow" $(O d .5,327)$. The north wind is the one that Vergil had left out from the list of winds at Aen. 1, 8586, and the one he returns to after Aeneas' speech (v. 102-103).

${ }^{19}$ Hence, the feminine form $\kappa \alpha \tau$ ' ö $\kappa \rho \eta \varsigma$, as Hainsworth noted in Heubeck, West, Hainsworth (1988: 281 ad Od. 5, 313).
} 
At the same time in v. 105 Vergil introduced a curious rhythmical effect by ending his hexameter with the abrupt monosyllabic mons, thus suggesting the suddenness with which the wave came down on the Trojan ships ${ }^{20}$. Eduard Norden cited as parallel for praerutus aquae mons the only preserved poetic fragment of Dionysius Iambus, teacher of no other than Aristophanes of

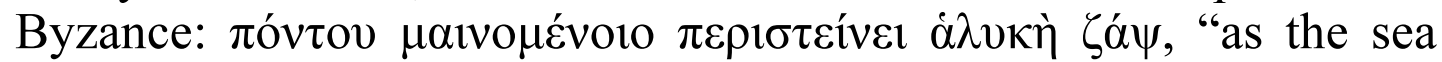

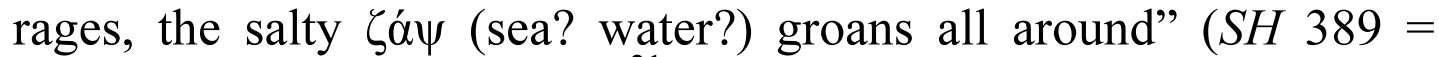
Clem. Alex. Strom. 5, 47, 1) ${ }^{21}$. However, as the description of the sea is very different in Aen. 1, 150 and in this fragment, it seems probable that Vergil was primarily following the description in $\mathrm{Od}$. $5,313-314$, while the idea that the sudden appearance of the great wave could be reinforced on the level of rhythm by ending the verse with a monosyllable might have been suggested to him by Homer's

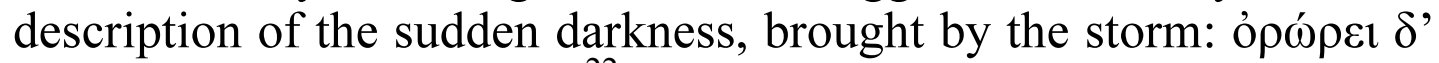

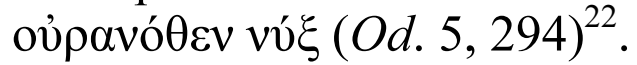

Thus, a closer look at Vergil's mode of alluding to Homer in v. 81-105 shows an intricate web of references of different types. The programmatic intent in Vergil's use of intertextuality in this scene is evident, and even more importantly, has a double aim: not only does Vergil seek to establish Aeneas as equivalent to, or even surpassing, Homer's Odysseus (as manifest in the extensive use of parallels and even accurate translations from the episode of the sea-storm in Odyssey 5), but he also positions himself as the Roman Homer (as he further enriches the scene with references to different Homeric passages and recognizable epic expressions, but also to his Roman predecessors, such as Pacuvius in v. 87 and Livius Andronicus in v. 92). In the following lines the concentration of Homeric elements, references and allusions is much smaller ${ }^{23}$. Vergil does not

${ }^{20}$ On the effect of aquae mons, see Austin (1971: 58 ad Aen. 1, 105), Hough (1975: 22).

${ }^{21}$ Norden 1903, 431 (Anhang IX.3.a). The fragment is cited by Clement of



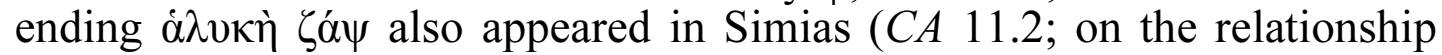
between Simias' and Dionysius' fragments, see Kwapisz 2019: 35 n.70).

${ }^{22}$ This verse will be rendered by Vergil in content, as well as in its rhythmical peculiarity, later on in Aeneas' account of the night when Troy was taken: ruit Oceano nox (Aen. 2, 250).

${ }^{23} \mathrm{Cf}$. dorsum immane mari summo (v. 110) which looks back to the

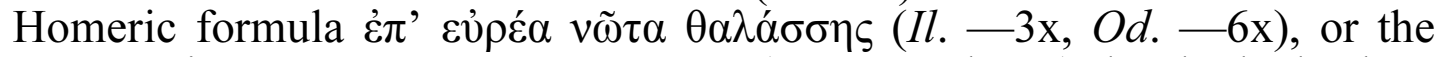
construction tris Notus... tris Eurus... (v. 108 and 110) that looks back to

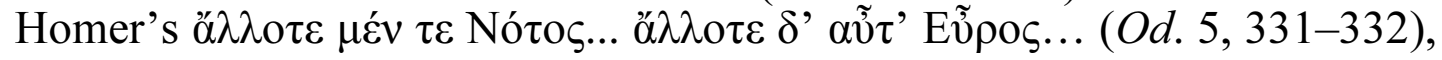


altogether lose sight of his Homeric model, but nor does he feel the need to follow it in detail, especially in view of the differences in context (in Homer Odysseus was alone in the storm, whereas Vergil has to describe what was happening not only to Aeneas, but to the whole of the Trojan fleet).

To what extent then was this complex play with the Homeric epics recognized by Vergil's ancient readers? Most of the commentaries make it difficult to say. Thus, when commenting this scene, Servius mentions Homer on minor points, but consistently avoids any remarks on Vergil's translation of Homeric expressions $^{24}$. Similarly, Tiberius Claudius Donatus in his Interpretationes Vergilianae, when discussing Aeneas' emotions and reactions throughout the scene of the storm, does not mention Homer, although it would have served his purpose to point out that Vergil was drawing on the Odyssey ${ }^{25}$. However, a glimpse of the ancient commentators' view of the use Vergil made of Homer can be gained the augmented version of Servius' commentary, also called the Servius Danielis and the Servius auctus, represented by several manuscripts where the original commentary is supplemented with remarks from earlier scholarship (these additions were probably made in the VII cent. AD $^{26}$. Servius Danielis preserves several remarks that show that not only was Vergil's use of Homer in this episode recognized, but it was also subject of critical debate. While it does not seem possible to trace these comments back to one certain source, most scholars agree that the Servius Danielis incorporated strands of earlier scholarship (in particular, Donatus). The notes on Vergil's rendering of Homer in the episode of the storm will be quoted with a translation and compared to Servius'

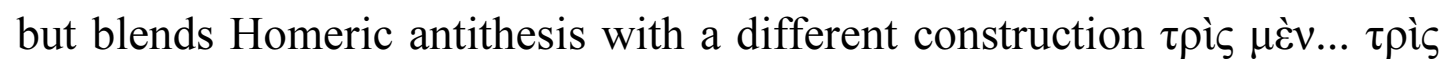
$\delta \grave{\varepsilon} . .$. , also frequently used by Homer (cf. Il. 5, 436-437; 8, 169-170; 11, $462-463$; 16, 702-703; 11, 784-785; 18, 155-157; 8, 228-229; 20; 445446; 21, 176-177; Od. 9, 361; 11, 206-207; 12, 105; 21, 125-126).

${ }^{24}$ Homer is mentioned explicitly in three notes: in the first case, Servius says that Homer viewed death at sea as a bad way to die (Serv. ad Aen. 1, 93); in the second case, he notes, quite accurately, that the name $\Sigma \alpha \rho \pi \eta \delta \omega ́ v$

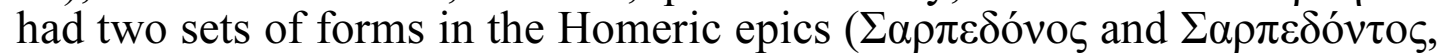
Serv. ad Aen. 1, 100); finally, in the note on Aen. 1, 96 he mentions that, according to Homer, Diomedes had wounded both Aphrodite and Ares.

${ }^{25}$ See Tib. Claud. Donat. p. 32-33 Georges. On Tiberius Claudius Donatus and his approach to the Aeneid, see Starr (1992), Pelttari (2014: 34-35).

${ }^{26}$ On Servius Danielis, as well as on the date and sources of these supplementary notes, see Goold 1970: 102-121 and, more recently, JeunetMancy 2012: XXI-XXVII. 
commentary ad loc., in order to reconstruct a fuller picture of the ancient philological tradition on each of these passages.

SD ad Aen. 1, 85. When discussing the list of winds given by Vergil in v. 85-86, Servius Danielis does not state that the first part of the list is a close translation from Homer, but his note shows that he was surely aware of it:

VNA EVRVSQVE NOTVSQVE ET AFRICVS] bene modo hos tres ventos inferiores tantum nominavit, qui a sedibus imis mare commovent, Zephyrum et Aquilonem tacuit; Zephyrum, qui ad Italiam ducit, Aquilonem, qui desuper flat. ideo Homerus de eo "каì ßopéns

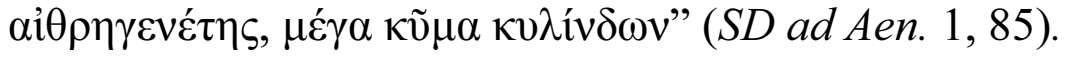

TOGETHER EURUS AND NOTUS, AND AFRICUS... [the poet] did well to name only three lower winds that agitate the sea from its outmost depths, and to pass in silence Zephyrus and Aquilo; Zephyrus that blows toward Italy, Aquilo that blows from above. Similarly, Homer


$\kappa \tilde{v} \mu \alpha \kappa \nu \lambda i ́ v \delta \omega v "$ ".

Servius in his commentary to this passage had noted that Vergil chose to name only three of the four cardinal winds, and that he will mention the north wind, Aquilo, at v. 102: the wording cardinales quattuor venti sunt, de quibus nunc tres ponit, "there are four cardinal winds, of which [Vergil] now gives three", shows that Servius had more or less equated Africus (the south-wester) with Zephyrus (the west wind). The compilator who had augmented his commentary refers to a different tradition, according to which Vergil had taken into account the direction of the winds, so that Zephyrus was replaced by Africus in order to avoid directing the Trojans straight to Italy, while Africus would have suggested that they will reach the shore near Carthage; the omission of Aquilo in v. 85 would then also explained by its direction ${ }^{27}$. The note does not state that the list of winds in Aen. 1, 85-86 was inspired by Homer, but this idea is implied (a) by the discussion of why Zephyrus was left out, and (b) by the quotation of the verse describing Boreas $(\mathrm{Od}$. 5, 296). It is, however, not evident why the scholiast felt the need to insert the Homeric quotation at this point (after all, Aquilo has deliberately been left unmentioned in Aen. 1, 85-86).

SD ad Aen. 1, 92. The note falls into two parts, the first discussing the origins of Vergil's expression solvuntur frigore

\footnotetext{
${ }^{27}$ The compiler of Servius Danielis will return to the omission of Aquilo in the list of winds (Aen. 1, 85-86) in his note to v. 102: ecce hic reddit ventum quem transierat, et a generali tempestate ad speciem transit.
} 
membra, the second reflecting the ancient critics' disapproval of the depiction of Aeneas at his first appearance.

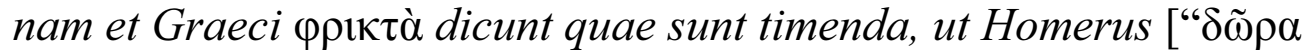

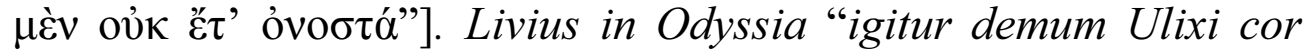
frixit prae pavore". reprehenditur sane hoc loco Vergilius, quod

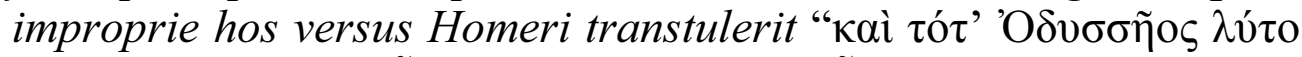

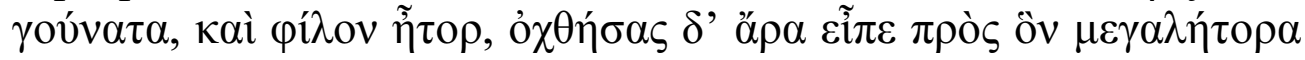
$\theta 0 \mu$ óv". nam 'solvuntur frigore membra' longe aliud est, quam $\lambda \hat{\tau} \tau \mathrm{o}$

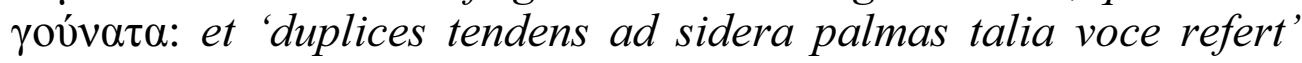
molle, cum illud magis altum et heroicae personae $\pi$ ò̀



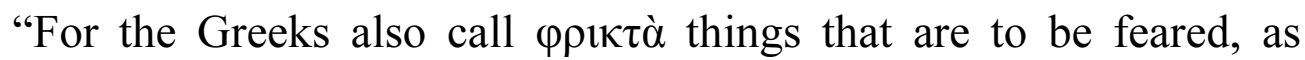
Homer... Livius in his Odyssia: igitur demum Ulixi cor frixit prae pavore. Vergil is criticized here on the grounds that he improperly

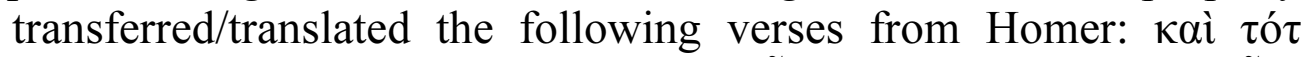

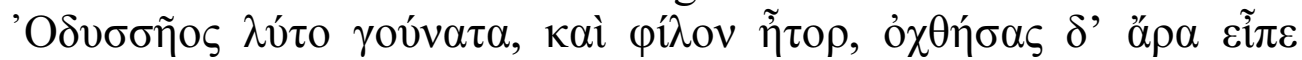

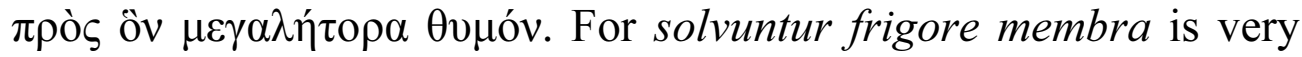

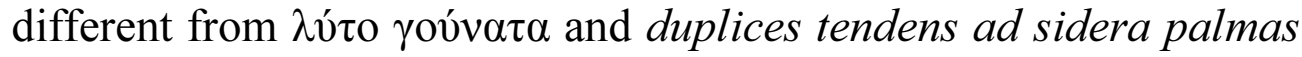
talia voce refert is weak, while the words $\pi \rho$ òs ôv $\mu \varepsilon \gamma \alpha \lambda \eta \dot{\tau} \tau \rho \rho \alpha$ $\theta v \mu o ́ v$ are to a greater degree elevated and better suit a heroic character".

Servius Danielis expands here on Servius' original note. Servius had set out to show that frigore stood for timore, as a metonymic substitution (cold - fear) that could in fact be applied both ways (i. e. timor could stand for frigus, and vice versa; Servius calls it reciproca translatio $)^{28}$. This interpretation and the very possibility of such semantic development is illustrated by a parallel from Terence (Hec. 320-321), as well as by a verse from the Georgics (1, 93). Incidentally, here Servius differs from Tiberius Claudius Donatus who was not ready to admit that Vergil could have depicted Aeneas as terrified, and therefore interpreted frigore as referring to the hero's feeling an actual chill in the face of the coming storm ${ }^{29}$. Servius, on the other hand, states unequivocally "FRIGORE timore",

\footnotetext{
${ }^{28}$ On the notion of reciproca translatio and on Servius' note see the excellent analysis by Monique Bouquet (2016: 255-256).

${ }^{29}$ Recte ergo non timorem, sed verum frigus debemus intellegere, quod oriebatur ex tot adversis quae corporis calores extinxerant (Tib. Claud. Donat. Interpret. Verg. p. 32 Georges). The idea that Aeneas was terrified not of the storm, but of death by drowning, that Donatus proposes, will be taken up by Servius as well, in the note to Aen. 1,93 though he attributes the origins of this idea to Homer. See Starr (1992: 162) on the difference in Tib. Claudius Donatus' approach to solvuntur frigore membra from that of Servius Danielis.
} 
explaining that Vergil had preserved decorum in making Aeneas the last of the Trojans to feel fear. This is one of the parts of Servius' commentary where the absence of any mention of Homeric parallels in glaring - and certainly deliberate ${ }^{30}$.

Servius' note is supplemented in Servius Danielis that introduces a different perspective on the word frigore, citing parallels from the Greek. The first parallel, $\varphi \rho \iota \kappa \tau$ ' $\varsigma$ ("one who gives you the shivers", hence, "frightening, terrible") comes from later Greek usage $^{31}$, and must have been suggested to the scholar used by the compiler of Servius Danielis by its phonetic resemblance to frigus ${ }^{32}$. As regards the second Greek parallel, the text is corrupt: the words ut Homerus show that the scholiast had cited a Homeric example,

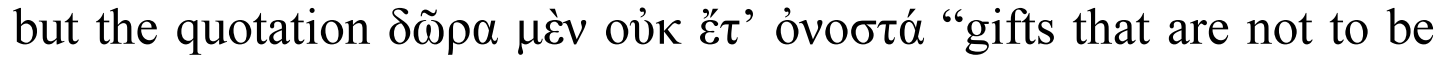
despised" $(I l .9,164)$ has nothing to do with the point that he had set out to illustrate. We are thus dealing with a lacuna. Thilo and Hagen in their edition place the quotation in square brackets, suggesting that it should be deleted, but that leaves the preceding words $u t$ Homerus hanging. In a similar vein, Friderich Schoell suggested that

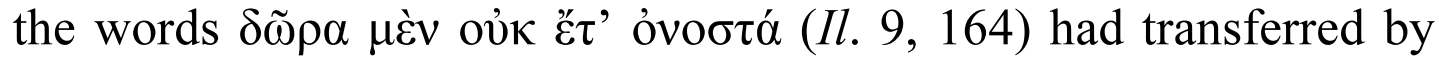
accident from the note on Aen. 1, 77, where Aeolus' words munera nec sperno, "I scorn not your gifts", were explained by Servius: item (scil. litotes - M. K.) munera nec sperno, id est libenter accipio, "munera nec sperno is likewise a litotes, that is, I readily accept"33. This obviously leaves us with the same lacuna, while the transfer of

${ }^{30}$ The fact that Servius chose to voluntarily omit all mention of Vergil's use of Homer in Aen. 1, 92, is pointed out by Keeline 2013, 72. This was not due to Servius' lack of interest in Homer (and Greek in general): his commentary was written for pedagogical reasons, and he often chose to exclude the discussion of Homeric parallels that had been noted by his predecessors so as not to overburden his commentary with information that was irrelevant to his immediate teaching aims (see Racine 2015; cf. Kaster 1997: 170-171).

${ }^{31}$ The verbal adjective $\varphi \rho \imath \kappa \tau$ ó $\varsigma$ comes into use starting from the Hellenistic times (cf. Call. Aet. 3, 1, 6; Anth. Pal. 6, 219; 7, 405; Philod. D. 1, 17; Plut. Cic. 49; Num. 10; etc.).

${ }^{32}$ This is a case of popular etymology, for while the etymology of $\varphi$ pí $\sigma \omega$ is not definitely established, Latin frigus finds its Greek counterpart in

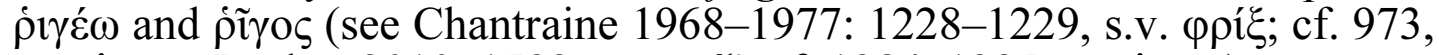

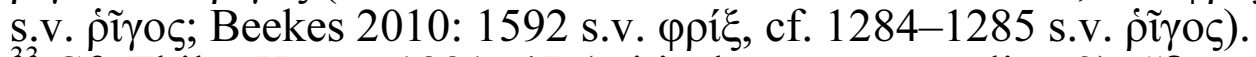

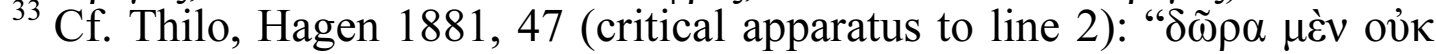
ह̌ $\tau$ ' ỏvootá (Il. IX 104) quae huc non pertinere apparet, F. Schoellius coniecit ad 'munera nec sperno', quae verba Servius ad v. 77 laudat, adscripta fuisse et errore vel librarii alicuius vel eius qui Scioppii collationem Danielis Servio adaptabat huc delata esse". 
the Homeric quotation from the note on Aen. 1, 77 to that on Aen. 1, 92 would appear to be totally arbitrary. I would like to suggest a different solution. Probably the closest Homeric parallel for the semantic development "cold $\rightarrow$ fear" that the Vergilian critic (the source of Servius Danielis) would have cited is the verb $\dot{\rho} \gamma \varepsilon \dot{\varepsilon} \omega$, regularly used by Homer to describe the stunned and awed reaction of his characters, e. g.:



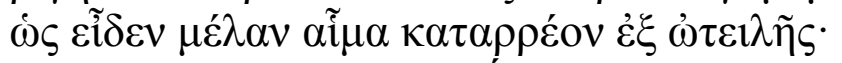

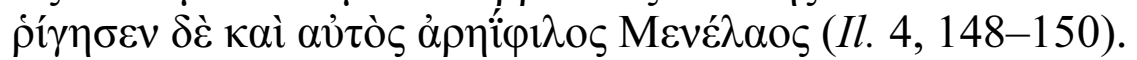

"And Agamemnon, the leader of men, froze as he saw black blood flowing down from the open wound, and Menelaus, dear to Ares, himself froze as well".

Not only is this use of $\dot{\rho} \gamma \varepsilon \dot{\varepsilon} \omega$ a close parallel that would have suggested itself to a competent scholar, well versed in Vergilian problems, but also well acquainted with the Homeric poems, but the likelihood of its having been evoked by ancient scholars is confirmed by Macrobius' Saturnalia, where Vergil's description of Aeneas' reaction to the coming storm $($ Aen. 1,92$)$ is explained as a compilation of two Homeric verses:



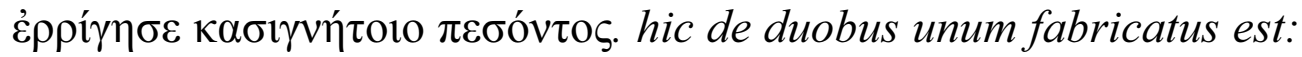
extemplo Aeneae solvuntur frigore membra (Macrob. Sat. 5, 3, 9 Willis).

“'And then were Odysseus' knees and his heart loosened' and elsewhere 'Ajax froze as his brother fell'. [Vergil] from these two verses created one: extemplo Aeneae solvuntur frigore membra".

Now, the curious fact about this passage is that, were we to look

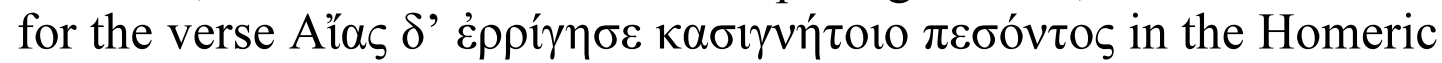
poems, we would not find it: the editor of the Saturnalia, Jacob Willis $(1994,249)$ in his critical apparatus refers to two passages,

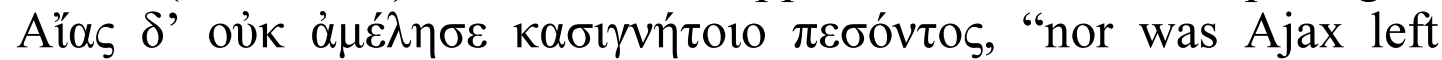

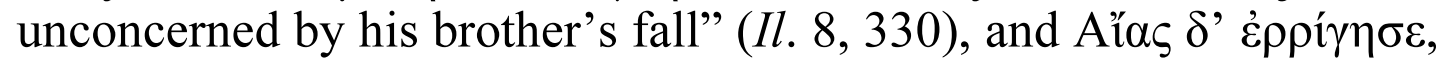
$\kappa \alpha \sigma i ́ \gamma v \eta \tau o v \delta \grave{\varepsilon} \pi \rho \circ \sigma \eta v ́ \delta \alpha$ "Ajax froze, and addressed his brother" (Il. $15,436)$. It seems that either Macrobius knew a varia lectio for $I l$. 8 , 330 (that is not reflected in the extant Homeric manuscripts), or that he had actually conflated $I l .8,330$ with $I l .15,436 .{ }^{34}$ Whichever the

\footnotetext{
${ }^{34}$ West in his apparatus criticus to this passage does not commit himself

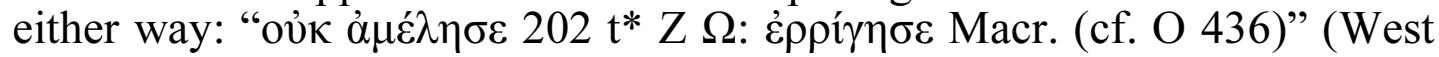
2006, 240, apparatus criticus on v. 330).
} 


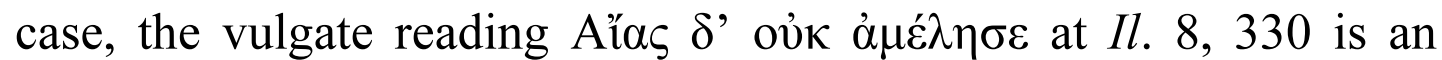
excellent example of a litotes, and - returning to the question of the

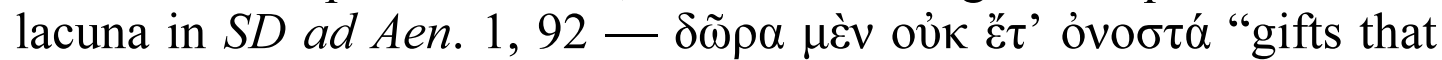
are not to be despised" $(I l .9,164)$ could very well have been quoted by the scholar that the compiler of Servius Danielis drew on as another example of the same figure (the choice of this verse to illustrate the phenomenon of litotes would have been suggested by its having appeared in the same commentary not long before, in the discussion of Aeolus' words, munera nec sperno at Aen. 1, 77). Thus, despite an evident lacuna in Servius Danielis, the logic that

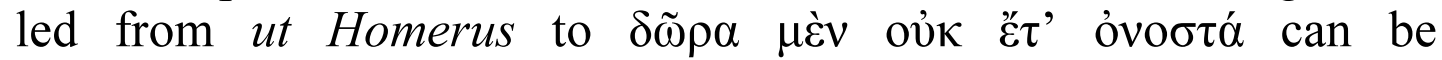
reconstructed with a fair degree of certainty, if one admits that the compiler of Servius Danielis was relying on a commentary that contained a deep and erudite discussion of the Aeneid and made extensive use of Homeric epics while commenting on Vergil's text. The same commentary must have showed awareness of Vergil's use of early Roman poetry, recognizing, in this particular case, that the poet was taking into account Livius Andronicus' rendering of the same verse (as already stated, it is thanks to Servius Danielis that this verse is preserved).

The next phrase of the note on Aen. 1, 92 switches to a different, much more critical tradition (if not actually a different scholarly source), a change that is marked by the words reprehenditur sane hoc loco Vergilius... While the first part of Servius Danielis' note had sought to explain Vergil's choice of expressions through the discussion of semantic development and introduction of parallels from Vergil's predecessors, this second part of the note focuses on criticizing Vergil for the ungainly traits in his portrait of Aeneas. Homer's influence in this passage is recognized and remarked upon, but Vergil's adaptation of the Homeric model is considered as lacking in finesse. Thus, the scholiast of Servius Danielis goes on to state, rather surprisingly, that solvuntur frigore membra is very

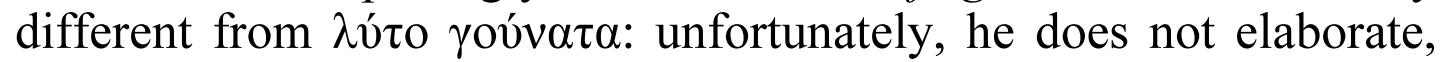
but if one can judge from the second part of the same sentence that reprehends Vergil's duplices tendens ad sidera palmas as too soft in comparison with Homer's $\pi \rho$ ò $\varsigma$ ôv $\mu \varepsilon \gamma \alpha \lambda \eta ́ \tau o \rho \alpha ~ \theta v \mu o ́ v$, it can be concluded that the scholiast felt that solvuntur frigore membra presented Aeneas in a more negative light than the words $\lambda v \tau_{0}$ 


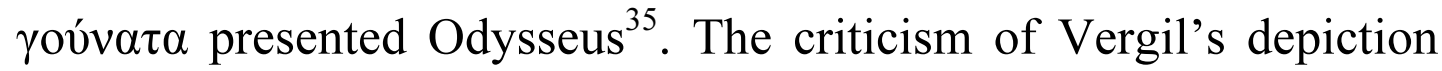
of Aeneas continues with a series of rhetorical questions:

praeterea quis interdiu manus ad sidera tollit, aut quis ad caelum manum tendens non aliud precatur potius, quam dicit 'o terque quaterque beati'? et ille intra se, ne exaudiant socii et timidiores despondeant animo, hic vero vociferatur (SD ad Aen. 1, 92).

Moreover, who in daytime raises his hands to the stars, or who when raising his hand to the sky does not pray something else, rather than saying o terque quaterque beati? And the former (i. e. Odysseus) had spoken to himself, so that his companions should not hear and so that those who were more timid, not lose heart, the latter (i. e. Aeneas) indeed raises his voice.

The scholiast (or rather his source) noticed the slight illogicality behind Aeneas' gesture (manus ad sidera tollit) without recognizing that Vergil was adapting $I l .15,371$ where the same criticism could be applied (se above). He then points out the discrepancy between the gesture and Aeneas' exclamation, ${ }^{36}$ as well as the fact that a good leader would be expected to keep his fears and lamentations to himself. The second part of the note in Servius Danielis draws on a philological tradition that compared Aeneas' actions and words in the sea-storm against Homer's depiction of Odysseus: this tradition was fully aware of Vergil's translation and adaptation of Homeric expressions, but reproached him for not making Aeneas act more heroically than he does ${ }^{37}$. It is not possible to establish definitely which of the Vergilian critic Servius Danielis was drawing on in this note, but Aelius Donatus has been suggested as a possible source ${ }^{38}$.

${ }^{35}$ The reasoning behind a judgement of this kind is not easy to reconstruct; possibly, the feeling of weakness at the knees only was felt as being less reprehensible than the general numbness of limbs. The main point for the critic summarized in Servius Danielis, however, was that Aeneas' portrait lacked heroic traits (cf. de Grummond 1977: 224-225, 228), and all other points of criticism were added so as to strengthen this reproach.

${ }_{36}^{36}$ Cf. Anderson (1993: 167, especially note 9).

${ }^{37}$ For a harsh (and rather unfair) view of the critics summarized in $S D$ ad Aen. 1, 92, cf. Austin (1971: 55 ad Aen. 1, 92): "Apart from these absurdities, these earnest critics seem not to have noticed that in $\mathrm{Od}$. 1.c. Odysseus was alone".

${ }^{38}$ Keeline (2013: 71), who considers that ironic rhetorical questions as a stylistic trait that might have been characteristic of Aelius Donatus' commentary: "I wonder if this sarcasm is a distinctive feature of Donatus' voice. We have already seen it above and it recurs frequently" (ibid., n. 30). 
SD ad Aen. 1, 94. Once again, the scholiast quotes Homer's expression that Vergil had translated into Latin, and that Servius had decided not to comment on:

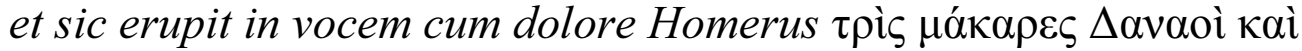

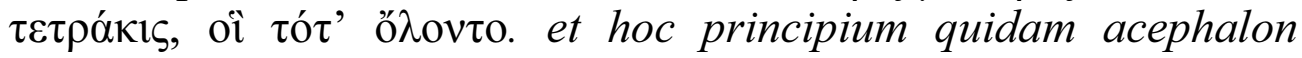
dicunt, cum intellegi debeat, multa eum intra se cogitasse, postremo in haec erupisse (SD ad Aen. 1, 94)



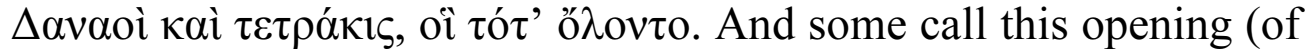
speech) lacking a beginning (acephalon), whereas it should be understood that [Aeneas] had been considering much within his heart, and broke out then into this cry".

Servius at this point only remarks on the adverbs terque quaterque, as a stylistic peculiarity that his students should take note of: O TERQVE QVATERQVE id est saepius; finitus numerus pro infinito, "that is to say, many times over; the finite number is used for an infinite" (Serv. ad Aen. 1, 94). Servius Danielis, on the other hand, not only recognizes that Vergil was once again adapting Homer, but also mentions a critical tradition that called Aeneas' exclamation acephalon: this idea (as well as the use of Greek rhetorical terminology) must have originated within a critical comparison of Aeneas' and Odysseus' speeches: the former could be called acephalon, as Aeneas begins directly with the exclamation, whereas in Homer the exclamation appears in the middle of Odysseus' speech. However, in this case the scholiast (and possibly, his source) is ready to defend Vergil against criticism, saying that the abruptness of the opening words is suggestive how much Aeneas had on his mind.

Thus, the pieces of scholarship on Aen. 1, 81-105 preserved in Servius Danielis give us a glimpse of what was certainly a rich tradition of comparing the sea-storm at Aen. 1, 81ff. with the seastorm at $O d .5,291 \mathrm{ff}$. It is fairly certain that a number of critics attempted comparisons of this kind, and although none of the notes can be attributed to any given scholar, it is a plausible guess that Aelius Donatus would have influenced the three notes in Servius Danielis that were examined above. These notes show that Vergilian

\footnotetext{
39 There might be a minor lacuna after dolore because technically, $\tau \rho i{ } \varsigma$

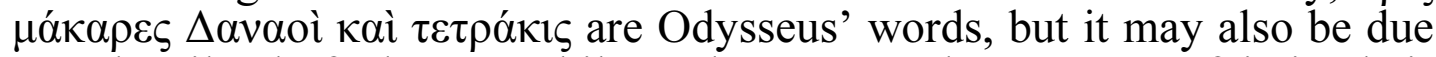
to a hastily drafted note. Thilo and Hagen make no note of it in their edition.
} 
scholars recognized Vergil's intertext in this episode and compared the two storms in detail, highlighting the expressions that Vergil copied from Homer. However, they seem to have failed, in general, to notice the cases where Vergil adapting an expression that had Homeric origins, but was taken from other parts of Homeric epos (this is especially manifest in the case of the scholarly tradition on Aen. 1, 93). On the whole, these notes testify to the ancient scholars' acumen in detecting both the points where Vergil was copying Homer, but also when he chose to depart from his model (as in the modified and reduced list of winds ad Aen. 1, 85-86). It also appears that the critic(s) summarized by Servius Danielis considered accurate rendering of the Homeric expression into Latin of secondary importance in comparison to the general aims of depicting a heroic character with Homeric overtone: thus, although at Aen. 1, 92 solvuntur frigore membra is a fairly close rendering of $\lambda \hat{\tau} \tau \mathrm{o}$

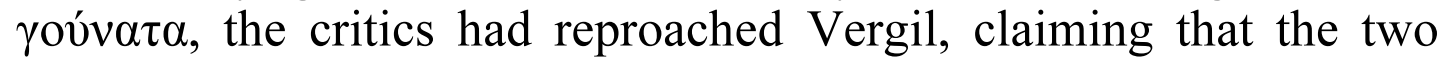
verses were vastly different in effect (longe aliud est).

\section{References}

Anderson, W. S. 1993: The Suppliant's Voice and Gesture in Vergil and Ovid's Metamorphoses. Illinois Classical Studies 18, 165-177.

Austin, R. G. (ed., comm.) 1971: Vergili Maronis Aeneidos liber primus. Oxford: Clarendon Press.

Barchiesi, A. 2015: Homeric Effects in Vergil's Narrative, translated by I. Marchesi, M. Foxx, foreword by Ph. Hardie. Princeton; Oxford: Princeton University Press.

Beekes R. 2010: Etymological dictionary of Greek, with the assistance of L. van Beek. Vol. I-II. Leiden: E. J. Brill.

Bouquet, M. 2016: Le processus métaphorique dans les commentaires serviens. In: A. Garcea, M.-K. Lhommé, D. Vallat (eds.) Fragments d'érudition: Servius et le savoir antique. Hildesheim; Zürich; New York: Georg Olms, 239-258.

Chantraine P. 1968-1977: Dictionnaire étymologique de la langue grecque : histoire des mots. Vol. I-IV. Paris: Klincksieck.

Conington, J. (ed., comm.) 1863: P. Vergili Maronis Opera, with a commentary. Vol II. London: Whittaker and Co.; George Bell.

de Grummond, W. W. 1977: Aeneas Despairing. Hermes 105(2), 224-234.

de Jong, I. J. F. 2001: A Narratological Commentary on the Odyssey. Cambridge; New York: Cambridge University Press.

Faulkner, A. (ed., comm.) 2008: The Homeric Hymn to Aphrodite: Introduction, Text, Commentary. Oxford: Oxford University Press.

Galinski, G. K. 1969: Troiae qui primus ab oris... (Aen. I, 1). Latomus 28(1), 3-18.

Galinsky, G. K. 1996: Augustan Culture: An Interpretative Introduction. Princeton, New Jersey: Princeton University Press. 
Georges, H. (ed.) 1905-1906: Tiberi Claudi Donati Interpretationes Vergilianae. Vol. I-II. Leipzig: B. G. Teubner.

Goold, G. P. 1970: Servius and the Helen Episode. Harvard Studies in Classical Philology 74, 101-168.

Gossage, A. J. 1963: Aeneas at Sea. Phoenix 17(2), 131-136.

Heubeck, A. West, St. Hainsworth, J. B. 1988: A Commentary on Homer's Odyssey. Vol. I: Introduction and Books I-VIII. Oxford: Clarendon Press.

Hough, J. N. 1975: Monosyllabic Verse-Endings in the Aeneid. Classical Journal 71(1), 16-24.

Jeunet-Mancy, E. (ed., tr., comm.) 2012: Servius: Commentaire sur l'Énéide e Virgile. Paris: Les belles lettres.

Kaster, R. 1997: Guardians of Language: The Grammarian and Society in Late Antiquity. Berkeley; Los Angeles; Oxford: University of California Press.

Keeline, T. 2013: Did (Servius') Vergil Nod?. Vergilius 59, 61-80.

Knauer, G. N. 1964: Die Aeneis und Homer: Studien zur poetischen Technik Vergils mit Listen der Homerzitate in der Aeneis. Göttingen: Vandenhoeck \& Ruprecht.

Kwapisz, J. 2019: The Paradigm of Simias: Essays on Poetic Eccentricity (Trends in Classics 75). Berlin; Boston: Walter de Gruyter.

Lloyd-Jones, H. Parsons, P. (eds.) 1983: Supplementum Hellenisticum. Teil $1 /$ indices H.-G. Nesselrath. Berlin; New York: Walter de Gruyter.

Nehrkorn, H. 1971: A Homeric Episode in Vergil's Aeneid. American Journal of Philology 92(4) 566-584.

Norden, E. (ed., comm.) 1903: P. Vergilius Maro: Aeneis Buch VI. Leipzig: B. G. Teubner.

Pelttari, A. 2014: The Space that Remains: Reading Latin Poetry in Late Antiquity. Ithaca; London: Cornell University Press.

Philpott, P. 2016: Weak at the Knees: Two Iliadic Formulae. Greek, Roman, and Byzantine Studies 56, 398-409.

Pontani, F. (ed.) 2015: Scholia Graeca in Odysseam. Vol. III: scholia ad libros $\varepsilon-\zeta$. Roma: Edizioni di Storia e letteratura.

Pöschl, V. 1962: The Art of Vergil: Image and Symbol in the Aeneid, transl. G. Seligson. Ann Arbor: University of Michigan Press.

Powell, J. U. (ed.) 1925: Collectanea Alexandrina: Reliquiae minores poetarum Graecorum aetatis Ptolemaicae 323-146 A.C. epicorum, elegiacorum, lyricorum, ethicorum, cum epimetris et indice nominum. Oxford: Clarendon Press.

Pucci, P. 2012: Iterative and Syntactical Units: A Religious Gesture in the Iliad. In: Fr. Montanari, A. Rengakos, Chr. Tsagalis (eds.) Homeric Contexts: Neoanalysis and the Interpretation of Oral Poetry. Berlin; Boston: de Gruyter, 427-443.

Putnam, M. C. J. 1995: Virgil's Aeneid: Interpretation and Influence. Chapel Hill; London: University of North Carolina Press.

Racine, F. 2015: Servius' Greek Lessons. In: E. P. Archibald, W. Brockliss, J. Gnoza (eds.) Learning Latin and Greek from Antiquity to the Present. Cambridge: Cambridge University Press, 52-64.

Scott, W. C. 1974: The Oral Nature of Homeric Simile. Leiden: E. J. Brill. 
Starr, R. J. 1992: An Epic of Praise: Tiberius Claudius Donatus and Vergil's Aeneid. Classical Antiquity 11(1), 159-174.

Thilo, G. Hagen, H. 1881: Servii Grammatici quae feruntur in Vergilii carmina commentarii. Vol. I: Aeneidos librorum I-V commentarii. Leipzig: B. G. Teubner.

Thomas, R. F. 1986: Virgil's Georgics and the Art of Reference. Harvard Studies in Classical Philology 90, 171-198.

van der Valk, M. (ed.) 1971-1987: Eustathii Episcopi Thessalonicensis Commentarii ad Homeri Iliadem pertinentes ad fidem codicis Laurentianae editi. Vol. I-IV. Leiden: E. J. Brill.

Warmington, E. H. (ed., transl.) 1936: Remains of Old Latin. Vol. II: Livius Andronicus, Naevius, Pacuvius and Accius. Cambridge Mass.; London: William Heinemann, Harvard University Press.

Willis, J. (ed.) 1994: Ambrosii Theodosii Macrobii Saturnalia. Stuttgart; Leipzig: B. G. Teubner. 